\title{
KEMAMPUAN KONEKSI MATEMATIKA PESERTA DIDIK DALAM MENYELESAIKAN MASALAH MATEMATIKA PADA MATERI LINGKARAN MELALUI PEMBELAJARAN INKUIRI TERBIMBING DI KELAS VIII SMP MUHAMMADIYAH 4 KEBOMAS
}

\author{
Dian Rusiana $^{1}$, Sri Uchtiawati ${ }^{2}$, Nur Fauziyah ${ }^{3}$ \\ Universitas Muhammadiyah Gresik ${ }^{1}$ \\ dianrusiana65@gmail.com \\ Universitas Muhammadiyah Gresik ${ }^{2}$ \\ sri.uchtiawati@gmail.com \\ Universitas Muhammadiyah Gresik ${ }^{3}$ \\ nur_fauzia@yahoo.co.id
}

\begin{abstract}
Abstrak
Kemampuan koneksi matematika erat kaitannya dengan kemampuan peserta didik dalam menyelesaikan masalah matematika. Melalui kegiatan menyelesaikan masalah matematika peserta didik akan berusaha mencari konsep-konsep matematika yang memiliki keterkaitan dengan masalah yang dihadapi, kemudian menghubungkan konsep-konsep tersebut untuk menyelesaikannya. Salah satu pembelajaran yang dapat digunakan untuk melatih dan meningkatkan kemampuan koneksi matematika peserta didik adalah pembelajaran inkuiri terbimbing. Tujuan penelitian ini adalah untuk mendeskripsikan kemampuan koneksi matematika peserta didik berkemampuan tinggi, sedang, dan rendah dalam menyelesaikan masalah matematika pada materi lingkaran melalui pembelajaran inkuiri terbimbing di Kelas VIII SMP Muhammadiyah 4 Kebomas.

Penelitian ini merupakan penelitian deskriptif kuantitatif. Subjek pada penelitian ini adalah seluruh peserta didik kelas VIII-A SMP Muhammadiyah 4 Kebomas sebanyak 23 peserta didik. Metode yang digunakan adalah metode tes dan wawancara. Instrumen yang digunakan dalam penelitian ini adalah tes kemampuan matematika, tes kemampuan koneksi matematika, lembar validasi soal, dan pedoman wawancara.

Dari hasil analisis data, kemampuan koneksi matematika peserta didik yang berkemampuan tinggi termasuk kriteria baik dalam menyelesaikan masalah matematika pada materi lingkaran melalui pembelajaran inkuiri terbimbing dengan rata-rata sebesar 68,06\% dan baik dalam memenuhi ketiga indikator kemampuan koneksi matematika. Kemampuan koneksi matematika peserta didik yang berkemampuan sedang termasuk kriteria cukup baik dalam menyelesaikan masalah matematika pada materi lingkaran melalui pembelajaran inkuiri terbimbing dengan rata-rata sebesar 42,89\% dan kurang dalam memenuhi indikator koneksi antar topik matematika. Kemampuan koneksi matematika peserta didik yang berkemampuan rendah termasuk kriteria sangat kurang dalam menyelesaikan masalah matematika pada materi lingkaran melalui pembelajaran inkuiri terbimbing dengan rata-rata sebesar 15,28\% dan sangat kurang dalam memenuhi ketiga indikator kemampuan koneksi matematika.
\end{abstract}

Kata kunci: kemampuan, koneksi matematika, pemecahan masalah, pembelajaran inkuiri.

\begin{abstract}
The ability of mathematical connection is closely related to the ability of the students in solving math problems. The students will attempt to find out the mathematical concepts which have relevance with the problems that they faced through the activities of solving math problems, then connecting those concepts to solve them. One of the lessons that can be used to train and improve the students' mathematical connection ability is guided inquiry learning. The purpose of this study is to describe the students' ability of mathematical connection who have
\end{abstract}


high, medium, and low-ability in solving mathematical problems related to circle material through guided inquiry learning for VIII grade in SMP Muhammadiyah 4 Kebomas.

This study is a quantitative descriptive research. 23 of VIII grade students in SMP Muhammadiyah 4 Kebomas were as the subject. The methods used are test and interview method. The instruments used in this study are mathematic ability test, math connection ability test, question validation sheet, and guided interview.

The result of the data analysis showed that the ability of mathematical connection of the students who have high-capability included good criteria in solving mathematical problems on circle material through guided inquiry learning with an average of $68,06 \%$ and good in achieving the three indicators of mathematical connection capability. The ability of mathematical connection of the students who have moderate-capability included fairly good criteria in solving mathematical problems on circle material through guided inquiry learning with an average of $42,89 \%$ and less in achieving the three indicators of connection among topics within mathematics. Meanwhile, the ability of mathematical connection of the students who have low-capability included very poor criteria in solving mathematical problems on circle material through guided inquiry learning with an average of 15,28\% and very less in achieving the three indicators of mathematical connection capability.

Keywords: capability, mathematical connection, problem solving, inquiry learning. 
PENDAHULUAN

Matematika merupakan ilmu terstruktur yang terorganisasikan. Seperti yang diungkapkan Permana dan Sumarmo (2007) bahwa matematika merupakan suatu ilmu yang memiliki karakteristik diantaranya adalah terstruktur, hierarkis serta sistematis yang berarti bahwa suatu konsep serta prinsip yang termuat didalamnya memiliki keterkaitan satu sama lain. Oleh karena itu, dalam pembelajaran matematika tidak hanya memerlukan kemampuan dalam pemahaman konsep matematika saja, namun juga perlu adanya koneksi yang dapat menghubungkan konsep-konsep matematika yang saling berkaitan.

Koneksi yang diperlukan dalam pembelajaran matematika adalah koneksi matematika. Menurut Elly Susanti yang dikutip Fuadah (2016: 12) menjelaskan bahwa koneksi matematika adalah jembatan dimana pengetahuan sebelumnya atau pengetahuan baru digunakan untuk membangun atau memperkuat pemahaman tentang hubungan ide-ide matematika, konsep, alur atau representasi. Kusuma (2008) juga mengungkapkan bahwa kemampun koneksi matematika adalah kemampuan seseorang dalam memperlihatkan hubungan internal dan eksternal matematika, yang meliputi koneksi antar topik matematika, koneksi dengan disiplin ilmu lain, dan koneksi dengan kehidupan sehari-hari. Dengan demikian kemampuan koneksi matematika sangat dibutuhkan oleh peserta didik agar dapat memahami keterkaitan materi matematika dan mampu menerapkannya dalam menyelesaikan permasalahan yang dihadapi.

Kemampuan koneksi matematika erat kaitannya dengan kemampuan peserta didik dalam menyelesaikan masalah matematika. Melalui kegiatan menyelesaikan masalah matematika peserta didik akan berusaha mencari konsep-konsep matematika yang memiliki keterkaitan dengan masalah yang dihadapi, kemudian menghubungkan konsep-konsep tersebut untuk menyelesaikannya. Sehingga dalam kegiatan menyelesaikan masalah matematika peserta didik dapat mengetahui keterkaitan berbagai konsep matematika yang dipelajari. Hal ini sesuai dengan Muschla (2009: 20) yang mengungkapkan bahwa pada saat peserta didik mengerjakan tugas-tugasnya, mereka akan menemukan keterkaitan antara ideide yang akan memperluas pemahaman mereka terhadap masalah dan solusi serta membantu mereka menghargai keterkaitan matematika.

Kemampuan koneksi matematika setiap peserta didik pastilah berbeda sehingga penyelesaian masalah matematika yang dilakukan peserta didik juga berbeda. Perbedaan tersebut salah 
satunya dipengaruhi oleh kemampuan matematika peserta didik, seperti hasil penelitian yang dilakukan Fuadah (2016) menyatakan bahwa ada perbedaan kemampuan koneksi matematika peserta didik dalam menyelesaikan masalah matematika pada pembelajaran matematika dengan model AIR (Auditory, Intellesctually, Repetition) ditinjau dari kemampuan matematika kelompok tinggi, sedang rendah. Dari penelitian tersebut menunjukkan bahwa peserta didik dengan tingkat kemampuan yang berbeda akan memunculkan kemampuan koneksi peserta didik yang berbeda pula dalam menyelesaikan masalah.

Kemampuan koneksi matematika yang baik hanya bisa diperoleh bila peserta didik sendiri yang aktif meramu kemampuan koneksi matematikanya (Suparman, 2007). Jadi dalam proses belajar peserta didik harus diberi kesempatan untuk belajar aktif dan mandiri dalam menyelesaikan masalah matematika dengan menggunakan konsepkonsep matematika yang dipelajari sebelumnya sehingga peserta didik dapat meningkatkan kemampuan koneksi matematikanya dan proses belajar yang terjadi menjadi lebih bermakna.

Menurut teori belajar konstruktivistik yang dikembangkan oleh Piaget, pengetahuan itu akan lebih bermakna apabila dicari dan ditemukan sendiri oleh peserta didik. Sejak kecil menurut Piaget, setiap individu memiliki kemampuan untuk mengkonstruksi pengetahuannya sendiri. Pengetahuan yang dikonstruksi oleh anak sebagai subjek, akan menjadi pengetahuan yang bermakna; sedangkan pengetahuan yang hanya diperoleh melalui proses pemberitahuan tidak akan menjadi pengetahuan yang bermakna, pengetahuan tersebut hanya untuk diingat sementara setelah itu dilupakan (Sanjaya, 2011: 124).

Berdasarkan teori konstruktivistik dikembangkan suatu strategi pembelajaran yaitu strategi pembelajaran inkuiri yang dapat digunakan guru dalam proses belajarnya. Dalam pembelajaran inkuiri terdapat tiga macam yaitu inkuiri terbimbing (guide inquiry), inkuiri bebas (free inquiry) dan inkuiri bebas yang dimodifikasi (modified free inquiry). Salah satu pendekatan inkuiri yang dapat diterapkan dalam pembelajaran pada tingkat Sekolah Menengah Pertama (SMP) adalah pembelajaran inkuiri terbimbing (guide inquiry). Hal ini sesuai dengan Sani (2013: 218) yang mengungkapkan bahwa pembelajaran inkuiri terbimbing dapat dilaksanakan mulai pada kelas 4 sampai dengan kelas 8 dan inkuiri bebas dapat dilaksanakan pada kelas 9 sampai dengan kelas 12. Pembelajaran inkuiri terbimbing adalah salah satu pembelajaran inkuri dimana dalam peroses belajarnya 
permasalahan atau pertanyaan diajukan oleh guru, guru membimbing peserta didik dalam melakukan penyelidikan dan peserta didik merencanakan prosedur penemuannya sendiri untuk memecahkan masalah yang diberikan (Sani 2013: 217). Dengan demikian dalam proses pembelajaran inkuiri terbimbing, peserta didik tidak hanya berperan sebagai penerima pelajaran melalui penjelasan guru, tetapi peserta didik berperan untuk menemukan sendiri inti dari materi yang diajarkan melalui proses penemuan.

Penerapan pembelajaran inkuiri terbimbing dimulai dari adanya kesadaran peserta didik tentang masalah yang ingin dipecahkan, jika masalah telah dipahami dengan jelas maka peserta didik akan lebih mudah untuk menyelesaikannya. Dalam menyelesaikan masalah, peserta didik akan aktif untuk mencari keterkaitan antara ideide atau konsep-konsep matematika yang terlibat dalam masalah yang diberikan, sehingga kemampuan koneksi peserta didik sangat diperlukan. Dari hasil penelitian sebelumnya yang dilakukan oleh Dhini Kusumawati (2010) menunjukkan bahwa kemampuan koneksi peserta didik yang menggunakan metode pembelajaran inkuiri terbimbing lebih baik dari kemampuan koneksi matematika peserta didik yang menggunkan metode konvensional. Oleh karena itu dengan menggunakan pembelajaran inkuiri terbimbing peserta didik dapat meningkatkan kemampuannya koneksi matematikanya melalui kegiatan pemecahan masalah.

Salah satu materi dalam matematika adalah lingkaran. Materi lingkaran memiliki keterkaitan dengan topik matematika lainya, dengan mata pelajaran lain, dan dengan kehidupan sehari-hari. Misalnya dalam mencari luas lingkaran peserta didik harus memahami materi perkalian dan perpangkatan dan pada subbab materi lain luas lingkaran digunakan untuk mencari garis singgung lingkaran (Zunanin, 2015).

Berdasarkan latar belakang masalah yang telah dikemukakan, maka rumusan masalah dari penelitian ini adalah bagaimana kemampuan koneksi matematika peserta didik yang berkemampuan tinggi, sedang, dan rendah dalam menyelesaikan masalah matematika pada materi lingkaran melalui pembelajaran inkuiri terbimbing di Kelas VIII SMP Muhammadiyah 4 Kebomas?.

Tujuan dalam penelitian ini adalah untuk mendeskripsikan kemampuan koneksi matematika peserta didik berkemampuan tinggi, sedang, dan rendah dalam menyelesaikan masalahmatematika pada materi lingkaran melalui pembelajaran inkuiri terbimbing di Kelas VIII SMP Muhammadiyah 4 Kebomas. 


\section{METODE PENELITIAN}

Jenis penelitian ini adalah penelitian deskriptif kuantitatif. Penelitian ini dilaksanakan di SMP Muhammadiyah 4 Kebomas yang beralamatkan di Jalan Sunan Prapen I/17 Giri Gresik.Subjek penelitian ini adalah peserta didik dari kelas VIII-A SMP Muhammadiyah 4 Kebomas tahun pelajaran 2016/2017 yang terdiri dari 23 peserta didik. Pemilihan subjek penelitian menggunakan teknik purposive samplingyaitu teknik penentuan sempel dengan pertimbangan khusus sehingga layak dijadikan sampel (Noor, 2011: 120).

Metode yang digunakan adalah metode tes yang dan wawancara. Instrumen yang digunakan dalam penelitian ini adalah: 1) Tes kemampuan matematika untuk mengelompokkan peserta didik dalam kriteria tinggi, sedang, dan rendah, 2) Tes kemampuan koneksi matematikauntuk mendapatkan data bagaimana kemampuan koneksi matematika peserta didik yang berkemampuan tinggi, sedang, rendah dalam menyelesaikan masalah matematika, 3) lembar validasi soal, dan 4) pedoman wawancara.

Instrumen tes yang digunakan dalam penelitian ini terlebih dahulu diuji validasi isi oleh validator. Selanjutnya akan diuji cobakan ke kelas lain yang tidak menjadi subjek penelitian untuk diuji validitas dan reliabilitasnya, kemudian hasilnya dianalisis dengan bantuan SPSS 16.0 .

Metode analisis data pada penelitian ini digunakan untuk mengolah data yang telah dikumpulkan oleh peneliti. Data yang diperoleh merupakan data nilai hasil tes kemampuan matematika, tes kemampuan koneksi matematika dan hasil wawancara peserta didik.

Prosedur penelitian yang digunakan dalam penelitian ini dibagi menjadi tiga tahap yaitu tahap persiapan, tahap pelaksanaan, dan tahap analisis data.

\section{HASIL DAN PEMBAHASAN}

Berdasarkan hasil tes kemampuan matematika peserta didik kelas VIII-A SMP Muhammadiyah 4 Kebomas dapat diketahui bahwa terdapat 3 peserta didik yang memiliki kemampuan matematika tinggi, kemudian terdapat 17 peserta didik yang memiliki kemampuan matematika sedang, dan terdapat 3 peserta didik yang memiliki kemampuan matematika rendah. Setelah peneliti mendapatkan hasil pengelompokkan peserta didik pada setiap kriteria (tinggi, sedang, dan rendah), selanjutnya peneliti melakukan proses pembelajaran inkuiri terbimbing pada materi keliling dan luas lingkaran untuk melatih dan meningkatkan kemampuan koneksi matematikanya melalui kegiatan pemecahan masalah. Pada saat pembelajaran inkuiri terbimbing peneliti 
bertindak sebagai guru yang menyediakan pedoman dan bimbingan kepada peserta didik, maka pembelajaran lebih berpusat kepada peserta didik. Rangkaian kegiatan pembelajaran pada penelitian ini dilakukan dalam bentuk kelompok, sehingga dalam proses belajarnya peserta didik dibagi menjadi kelompok-kelompok kecil yang terdiri dari 5 sampai 6 peserta didik. Pada saat berkelompok, peserta didik diberi LKK (Lembar Kerja Kelompok) yang berisi masalah matematika pada materi lingkaran yang harus diselesaikan sendiri bersama kelompoknya. Pemberian LKK (Lembar Kerja Kelompok) bertujuan untuk melatih dan meningkatkan kemampuan koneksi matematika peserta didik dalam menyelesaikan masalah. Setelah melakukan pembelajaran inkuiri terbimbing, peneliti melakukan tes kemampuan koneksi matematika pada materi keliling dan luas lingkaran untuk mendapatkan data bagaimana kemampuan koneksi matematika peserta didik yang berkemampuan tinggi, sedang, rendah dalam menyelesaikan masalah matematika. Kemampuan koneksi matematika peserta didik yang berkemampuan tinggi termasuk dalam kriteria baik dalam menyelesaikan masalah matematikapada materi lingkaran melalui pembelajaran inkuiri terbimbing dengan rata-rata sebesar $68,06 \%$. Pada kelompok peserta didik yang berkemampuan tinggi untuk indikator koneksi antar topik matematika memiliki rata-rata persentase sebesar $62,50 \%$ termasuk dalam kriteria baik, sedangkan indikator koneksi matematika dengan disiplin ilmu lain memperoleh rata-rata persentase sebesar $62,50 \%$ termasuk dalam kriteria baik, dan pada indikator koneksi matematika dengan dunia nyata atau dengan kehidupan seharihari memperoleh rata-rata persentase sebesar $79,17 \%$ termasuk dalam kriteria baik. Berdasarkan kriteria penilaian untuk setiap indikator, maka peserta didik yang berkemampuan tinggi baik dalam memenuhi ketiga indikator kemampuan koneksi matematika.

Kemampuan koneksi matematika peserta didik yang berkemampuan sedang termasuk kedalam kriteria cukup baik dalam menyelesaikan masalah matematikapada materi lingkaran melalui pembelajaran inkuiri terbimbing dengan rata-rata sebesar $42,89 \%$. Pada kelompok peserta didik yang berkemampuan sedang untuk indikator koneksi antar topik matematika memiliki rata-rata persentase sebesar 38,24\% termasuk kedalam kriteria kurang, sedangkan indikator koneksi matematika dengan disiplin ilmu lain memperoleh rata-rata persentase sebesar $41,18 \%$ termasuk kedalam kriteria cukup baik, dan pada indikator koneksi matematika dengan dunia nyata atau dengan kehidupan sehari-hari memperoleh 
rata-rata persentase sebesar 49,26\% termasuk kedalam kriteria cukup baik. Berdasarkan kriteria penilaian untuk setiap indikator, maka peserta didik yang berkemampuan sedang kurang dalam memenuhi indikator koneksi antar topik matematika.

Kemampuan koneksi matematika peserta didik yang berkemampuan rendahtermasuk kedalam kriteria sangat kurang dalam menyelesaikan masalah matematikapada materi lingkaran melalui pembelajaran inkuiri terbimbing dengan rata-rata sebesar 15,28\%. Pada peserta didik yang berkemampuan rendah untuk indikator koneksi antar topik matematika memiliki rata-rata persentase sebesar $12,50 \%$ termasuk dalam kriteria sangat kurang, sedangkan indikator koneksi matematika dengan disiplin ilmu lain memperoleh rata-rata persentase sebesar $12,50 \%$ termasuk dalam kriteria sangat kurang, dan pada indikator koneksi matematika dengan dunia nyata atau dengan kehidupan sehari-hari memperoleh rata-rata persentase sebesar 20,83\% termasuk dalam kriteria sangat kurang. Berdasarkan kriteria penilaian untuk setiap indikator, maka peserta didik yang berkemampuan rendahsangat kurang dalam memenuhi ketiga indikator kemampuan koneksi matematika.

\section{SIMPULAN}

Berdasarkan hasil analisis data, maka diperoleh kesimpulan bahwa kemampuan koneksi matematika peserta didik yang berkemampuan tinggi termasuk kriteria baik dalam menyelesaikan masalah matematikapada materi lingkaran melalui pembelajaran inkuiri terbimbing di Kelas VIII SMP Muhammadiyah 4 Kebomas dengan rata-rata sebesar $68,06 \%$. Peserta didik yang berkemampuan tinggi baik dalam memenuhi ketiga indikator kemampuan koneksi matematika.

Kemampuan koneksi matematika peserta didik yang berkemampuan sedang termasuk kriteria cukup baik dalam menyelesaikan masalah matematikapada materi lingkaran melalui pembelajaran inkuiri terbimbing di Kelas VIII SMP Muhammadiyah 4 Kebomas dengan ratarata sebesar $42,89 \%$. Peserta didik yang berkemampuan sedang kurang dalam memenuhi indikator koneksi antar topik matematika.

Kemampuan koneksi matematika peserta didik yang berkemampuan rendah termasuk kriteria sangat kurang dalam menyelesaikan masalah matematikapada materi lingkaran melalui pembelajaran inkuiri terbimbing di Kelas VIII SMP Muhammadiyah 4 Kebomas dan hanya memperoleh rata-rata sebesar 15,28\%. Peserta didik yang berkemampuan rendah 
sangat kurang dalam memenuhi ketiga indikator kemampuan koneksi matematika.

\section{DAFTAR PUSTAKA}

Abdurrahman, Mulyono. 2003. Pendidikan Bagi Anak Berkesulitan Belajar. Jakarta: Rineka Cipta.

Arikunto, Suharsimi dan Jabar, Cepi Sarifuddin Abdul. 2007. Evaluasi Program Pendidikan. Jakarta: PT. Bumi Aksara.

Arikunto, Suharsimi. 2010. Prosedur Penelitian Suatu Pendidikan Praktik. Jakarta: Rineka Cipta.

Arikunto, Suharsimi. 2013. Dasar-Dasar

Evaluasi Pendidikan. Jakarta: PT. Bumi Aksara.

Fitriana, Lia. 2015. Efektifitas Pembelajaran Konstruktivisme Terhadap Koneksi Matematika Kelas VIII Materi Faktorisasi Suku Aljabar MTs Madarijul Huda Kembang 2015/2016. Skripsi belum dipublikasikan. Semarang: Universitas Islam Negeri Walisongo.

Fuadah, Fakhriyatul. 2016. Profil

Kemampuan Koneksi Matematika Siswa dalam Menyelesaikan Masalah Matematika Pada Pembelajran Matematika dengan Model AIR (Auditory, Intellesctually, Repetition) Ditinjau dari Kemampuan Matematika. Skripsi belum dipublikasikan. Surabaya: UIN Sunan Ampel.

Hamalik, Oemar. 2003. Proses Belajar Mengajar. Bandung: PT. Bumi Aksara.

Jihad, Asep. 2008. Pengembangan Kurikulum Matematika. Bandung: Multi Pressindo.

Kusuma, Dianne Amor. 2008. Meningkatkan Kemampuan Koneksi Matematika dengan Menggunakan Pendekatan Konstruktivisme. Skripsi belum dipublikasikan. Bandung: Universitas Padjajaran.

Kusumawati, Dhini. 2010. Pengaruh Metode Inkuiri Terbimbing dalam Pembelejaran Matematika Terhadap Kemampuan Koneksi Matematika Siswa. Skripsi belum dipublikasikan. Jakarta: UIN Syarif Hidayatullah.

Lestari, Kurnia Eka dan Mohammad Ridwan Yudhanegara. 2015. Penelitian Pendidikan Matematika. Bandung: PT Refika Aditama.

Moleong, Lexy J. 2014. Metodologi Penelitian Kualitatif. Bandung: PT. Remaja Rosdakarya.

Mulyasa, E. 2005.Menjadi Guru Profesional Menciptakan Pembelajaran Kreatif dan Menyenangkan. Bandung: PT. Remaja Rosdakarya. 
Muschla, Judith. 2009. Pedoman Praktis

Tugas-Tugas Matematika. Jakarta: PT. Indeks.

NCTM. 2000. Principle and Standards for School Mathematics. USA: National Council of Teachers of Mathematic.

Noor, Juliansyah. 2011. Metodologi Penelitian. Jakarta: Prenada Media Group.

Permana, Yanto dan Utari Sumarmo. 2007. "Mengembangkan Kemampuan Penalaran dan Koneksi Matematik Siswa SMA Melalui Pembelajaran Berbasis Masalah". Educationist. Volume I Nomor 2 ISSN: 1907-8838: hal 117.

Posamentier, A.S., Jaye, D., Krulik, S. 2007."Problem -Solving Strategies for Efficient and Elegant Solutions: A Resource for the Mathematics Teacher". Corwin Press, Inc. California USA.

Robbins, Stephen P. 2000. Prinsip-Prinsip Perilaku Organisasi. Jakarta: Erlangga.

Romli, Muhammad. 2016. "Profil Koneksi Matematis Siswa Perempuan SMA dengan Kemampuan Matematika Tinggi dalam Menyelesaikan Masalah Matematika". MUST. Volume 1 Nomor 2: hal 8-27.

Sani, Ridwan Abdullah. 2013. Inovasi Pembelajaran. Bandung: PT. Bumi Aksara.
Sanjaya, Wina. 2011. Strategi Pembelajaran Berorientasi Standar Proses Pendidikan. Jakarta: Kencana Prenada Media.

Shadiq, Fadjar. 2014. Strategi Pemodelan pada Pemecahan Masalah Matematika. Yogyakarta: Graha Ilmu. Shofiana, Irma. 2015. Analisis Level Kemampuan Peserta Didik dalam Memecahkan Masalah Matematika Terbuka pada Materi Satuan Volume dan Deret Kelas VI SDN Siwalan. Skripsi belum dipublikasikan. Gresik: Universitas Muhammadiyah Gresik.

Siskawati, Fury Styo. 2014. Penalaran Siswa SMP dalam memecahkan Masalah Matematika Dintinjau dari Perbedaan Kepribadian Extrovert dan Introvert. Tesis belum dipublikasikan. Surabaya: Universitas Negeri Surabaya.

Sudjana, Nana. 2005. Metode Penelitian Kuantitatif, Kualitatif, dan $R \& D$. Bandung: PT. Remaja Rosdakarya.

Suharrnan. 2005. Psikologi Kognitif. Surabaya: Srikandi.

Suherman, Erman.2001. Common Text Book Strategi Pembelajaran Matematika Kontemporer. Bandung: UPI-JICA.

Suparman, Dedi. 2007. Meningkatkan Kemampuan Koneksi Matematikasiswa Madrasah Aliyah Melalui Metode Pembelajaran 
Generatif (Studi Eksperimen Terhadap Siswa Kelas X Madrasah Aliyah Negeri Bandung. Diakses pada 16 november 2016.http://digilipupi.edu.

Susanto, Ahmad. 2014. Teori Belajar dan Pembelajaran Disekolah Dasar. Jakarta: Kencana.

Trianto. 2011. Model-model Pembelajaran Inovatif Berorientasi Konstruktivistik. Jakarta: Prestasi Pustaka.

Ulep, dkk. 2000. High School Mathematics I \& II, Sourcebook on Practical Work for Teacher Trainers. Quezon City: SMEMPD.

Umami, Amelia Hidayatin. 2015. Kemampuan Koneksi Matematika Siswa dalam Pemecahan Masalah Ditinjau dari Gaya Kognitif ReflektifImpulsif. Skripsi belum dipublikasikan. Surabaya: Universitas Negeri Surabaya.
Widjajanti, Djamilah B. 2009. Kemampuan Pemecahan masalah Matematika Mahasiswa Calon Guru Maetematika: Apa dan Bagaimana Mengembangkannya. Makalah disampaikan pada Seminar Nasional FMIPA UNY di Yogyakarta, 5 Desember 2009.

Wijaya, Ariyadi. 2012. Pendidikan Matematika Realistik. Yogyakarta: Graha Ilmu.

Zunanin, Afifatul. 2015. Profil Kemampuan Koneksi Matematik Siswa dengan Metode Pembelajaran Blended Learning Pada Materi Lingkaran Siswa Kelas VII MTs Islamiyah Sukoharjo. Skripsi belum dipublikasikan. Kediri: Universitas Nusantara Persatuan Guru Republik Indonesia. 